$200-2576$

\title{
ORWL-848
}

Contract Io. $\mathrm{W}-7405$, eng 26

RRACTOP TECHOLOCY DIVISIOA

Photostat Price S

Mienofilm Price s

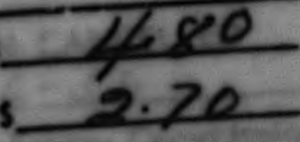

Available from the

Office of Technical Services

Departiment of Commerce

Washington 25, D. C.

THE CORROSION OF VARTOUS STATMLESS STEIELS III

SYNTHETIC WASTB sOLUTIONS

James L. Bnglish

Date Issued

\section{FEB 121951}

\section{UNCLASSIFIED}

OAK RIDGE IATIONAL LABORATORY operated by

CARBIDB AND CAFBON CHEMTCALS DIVISION

Union Carbide and Carbon Corporation

Post Office Box $\mathbf{P}$

Oak Ridge, Tennessee 


\section{$-3-$ \\ TABLS of COMHATS}

1.0 ABSIRACT

Page

2.0 IIIRODUCTIOH

5

3.0 TEST MATERIALS AID SOLUTIOAIS

5

4.0 TEST COIDITIOHS

6

5.0 CORrosion DaTa

7

7

6.0 DIscussion OF corRosion DATa

11

7.0 conclusions

23

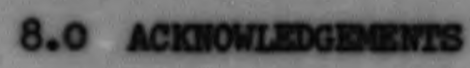

24 


\section{4-}

LIST OF TABLES AID FIGURES

I The Corrosion of 309 stainless Steel in Synthetic Waste Solutions

II The Corrosion of 316 stainless Steel in Synthetic Waste Solutions Solutiona

1 The Effect of Sodiu chloride Concentration on the Corrosion of Totelly Imersed Stainless Steels in Synthetic Waste Solutions

2 The Effect of Sodium Chloride Concentretion on the Corrosion of stainiess Steels Bxposed to the Liquid-Vapor Phase of Synthetic Waste Solutions

3 The Effect of Sodium Chloride Concentration on the Corrosion of Stainless Steels Exposed to the Vapor Phase of Synthetic Waste Solutions

4 Cumulative Neight Lossee on Steinless Steels Totaly Imersed In Waste Solution Ilo. 1

5 Cunulative Weight Losses on Stainless steels Totally Inersed in Weate Solution Ho. 2

6 Cunulative Weight Losses on Stainless Steels Totally Inersed in Waste Solution Ilo. 3

7 Cumulative Weight Losses on Btainless steels Exposed to the Liquid-Vapor Phese in Waste solution Wo. 1

20

8 Cunulative Weight Changes on Stainless Steels Bxposed to the Liquid-Vapor Phase in Waste. Solution Mlo. 2

Cumulative Weight Losses on Stainless Steels. Exposed to the Liguid-Vapor Phase in Waste Solution Blo. 3 


\subsection{ABSERMCT}

Types 309,316 , and 347 stainless stesl vere tested ror a totel of 779 to 828 hours in three different synthetic vaste solutions. The soaium chloride content of these solutions ranged rron 0.007 to $0.028 \mathrm{M}$. The tiest specimens vere checked under conditions of total inmersion, 11quid-vepor exposure, and exposure to the vapor phase. Tests vere run at boiling terperatures.

The best all-around corrosion resistance to the test conditions was exhibited by 316 stainless oteel although in one solution 3 h stainless steel was alightiy wore resistent. Maximan corrosion rates obtained in the most corrosive of the three solutions vere:

$\begin{array}{cc}\text { Type } 309 & 1.4 \mathrm{mils} / \mathrm{year} \\ \text { Type } 316 & 0.3 \mathrm{mil} / \mathrm{year} \\ \text { Type } 347 & 95.5 \mathrm{mils} / \mathrm{year}\end{array}$

\subsection{IERRODUCTIOE}

At the reçuest of Mr. T. A. Arehart of the Chemicel Technolog Division, a study was undertaken to inveotigate the corrosion resistance of various stainless steels in synthetic vaste solutions at bolling temeratures.

(1)

Along with the development of the tributyl phosphate process for recovery of uranium from Hanford metal waste solutions, the feesibility of recovering the free nitric acid content fros the tributyl phosphate waste was also studied. This latter proceso involves a continuous evaporation of the vaste to near the "freezing point" and concentrating the dilute acid vapors in a fractionating colum.

The process was proved sound econonically because of the ac1d and storage volume sevings, but a question of doubt was raised as to whether stainless steels could be utilized to handie the corrosive 1iquids. Some reports have indicated that the stainless etcrls vere corroded excessively by the presence of chlorides in the vaste solutione. . However, an inspection of equipaent used for a short time in the nitric ac1d recovery process from vastes contalning chlorides ald not verisy this report.

Therefore, in order to more clearly clarify the situation, an investigation was mede to determine the corrosion resistance of verious stainless steels in synthetic waste solutions containing different chioride concentrations. 


\subsection{TEST MATRRTATS}

Three types of itainless steels, 309, 316, and 347, vere investigated to deteraine their respective corrosion resistance to synthetie vaste solutions under various conditions of exposture. vare anchined trom cola $3.15 \mathrm{~cm}$ in diemeter and $0.45 \mathrm{~cm}$ in thickness area of the 250 m cold rolled bar stock. The average total surface to test, the specimens exposed to the test media vas $11.4 \mathrm{~cm}^{2}$. Prior to test, all samples vere polisbed, degreased, aried, and veighed.

The nominal chemical conpositions of the three stalnless steels used eprear below. Values are in percent.

\begin{tabular}{|c|c|c|c|}
\hline Element & Type_309 & Type 316 & Type 347 \\
\hline Carbon & 0.20 max. & 0.10 max. & 0.10 max. \\
\hline silicon & $\begin{array}{l}2.00 \text { max. } \\
0.75=2 \text {. }\end{array}$ & $2.00 \mathrm{max}$. & 2.00 max. \\
\hline Chroatum & $22.0-24.0$ & $\begin{array}{c}0.75 \text { max. } \\
16.0-18.0\end{array}$ & $\begin{array}{c}0.75 \text { max. } \\
17.0-19.0\end{array}$ \\
\hline Hickel & $12.0-15.0$ & $10.0-14.0$ & $9.0-12.0$ \\
\hline Hiobive & 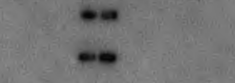 & $2.0-3.0$ & $8 \times e$ \\
\hline
\end{tabular}

Three synthetic vaste solutions were prepared vith increasing codiu chloride concentration. The solutions were made by dissolving nedie were:

\begin{tabular}{|c|c|c|c|}
\hline Nater1el & Solution 1 & Solution 2 & Solution 3 \\
\hline 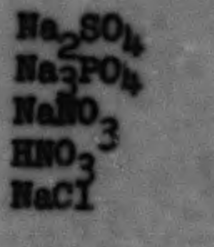 & $\begin{array}{l}0.18 \mathrm{~m} \\
0.18 \mathrm{~m} \\
2.00 \mathrm{M} \\
3.90 \mathrm{M} \\
0.007 \mathrm{~m}\end{array}$ & $\begin{array}{l}0.36 \mathrm{~m} \\
0.36 \mathrm{~m} \\
4.00 \mathrm{~m} \\
3.90 \mathrm{~m} \\
0.01 \mathrm{~m}\end{array}$ & $\begin{array}{l}0.18 \mathrm{~d} \\
0.18 \mathrm{~m} \\
2.00 \mathrm{~m} \\
3.90 \mathrm{M} \\
0.028 \mathrm{~m}\end{array}$ \\
\hline
\end{tabular}




\subsection{TEST COMDITIOHS}

A volume of $4000 \mathrm{ml}$ of solution vas used for each set of test specimens and was contained in a five liter cylindrical Pyrex flask. Solutions vere maintained at bolling temperatures during the course of the test under a condition of total reflux. Specimens vere suspended, by means of glass hooks, at three alfferent points in the corrosion environiment: total immersion, liquid-vapor interface, and the vapor phase. The position in the vapor phase was selected so that the specinen would also be contacted by the reflux liquid. Boiling temperature for Solution 1 and 3 was $105^{\circ} \mathrm{C}$; the boiling temperature for Solution 2 was $108^{\circ} \mathrm{C}$. Specimens vere removed at periodic intervals for velght change measurements in order to establiah velght change vs. time relationships. The total time of the tests ravged from 779 to 828 hours.

\subsection{CORROSION DATA}

The corrosion date obtained from this series of tests appear in the following tables. Results are cumulative.

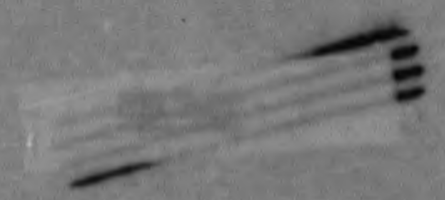




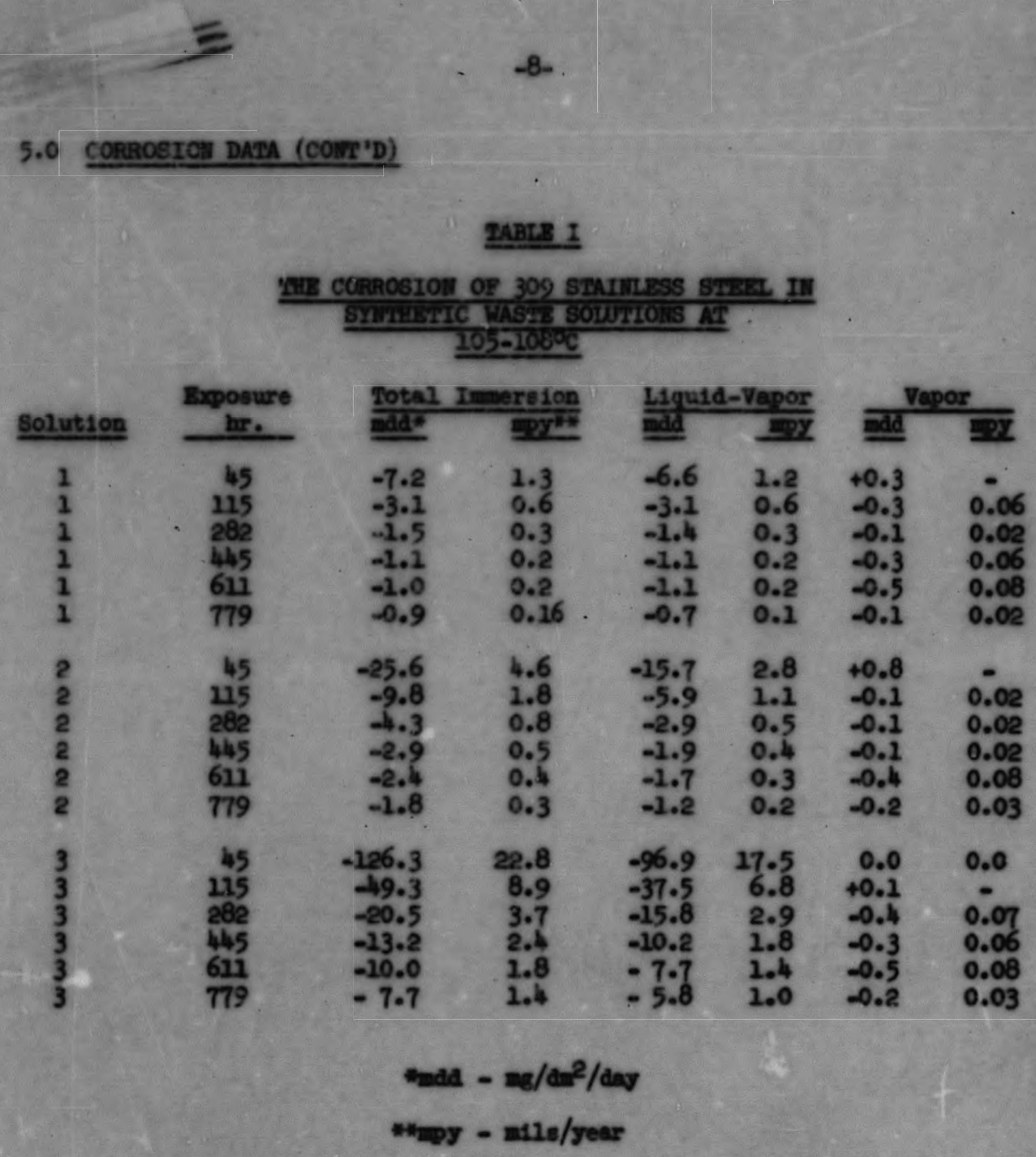




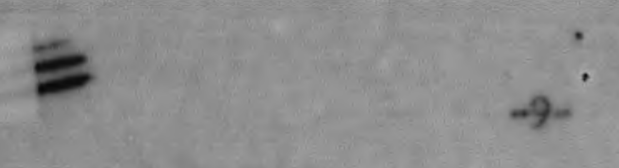

5.0 CORAOSION DATA (CONP'D)

\section{TABLB II}

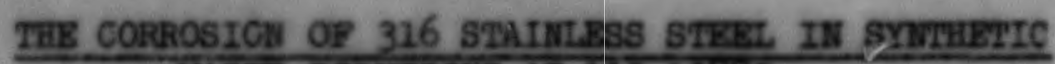
WASIE SOIUTIOIS AT $105-100^{\circ} \mathrm{C}$

\begin{tabular}{|c|c|c|c|c|c|c|c|}
\hline \multirow[b]{2}{*}{ Solution } & \multirow{2}{*}{$\begin{array}{l}\text { Expoeure } \\
\mathrm{hr}\end{array}$} & \multicolumn{2}{|c|}{ Total Immersion } & \multicolumn{2}{|c|}{ Liguid-Vapor } & \multicolumn{2}{|c|}{ Vapor } \\
\hline & & ndd & my & mda & 표y & mid & Impy \\
\hline 1 & 45 & -1.4 & 0.3 & -0.8 & 0.14 & 0.0 & 0.0 \\
\hline 1 & 115 & -0.4 & 0.08 & -0.2 & 0.04 & +0.4 & - \\
\hline 1 & 282 & -1.3 & 0.2 & -1.0 & 0.17 & -0.5 & 0.09 \\
\hline 1 & 445 & $-1 \cdot 3$ & 0.2 & -1.2 & 0.20 & -0.3 & 0.06 \\
\hline 1. & 611 & -1.4 & 0.3 & -1.0 & 0.19 & -0.5 & 0.08 \\
\hline 1 & 779 & -1.2 & 0.2 & -0.8 & 0.25 & -0.3 & 0.05 \\
\hline 8 & 45 & -1.4 & 0.30 & -0.5 & 0.09 & +1.40 & - \\
\hline 2 & 115 & -0.1 & 0.02 & +0.4 & - & +0.80 & - \\
\hline 2 & 282 & -0.8 & 0.14 & -0.4 & 0.08 & -0.04 & 0.007 \\
\hline 2 & 445 & -0.6 & 0.10 & -0.3 & 0.06 & -0.08 & 0.014 \\
\hline 2 & 611 & -0.8 & 0.14 & -0.6 & 0.11 & -0.28 & 0.051 \\
\hline 2 & 779 & -0.6 & 0.10 & -0.4 & 0.08 & -0.13 & 0.023 \\
\hline 3 & 45 & -1.1 & 0.20 & -0.5 & 0.01 & 0.0 & 0.00 \\
\hline 3 & 115 & -0.8 & 0.14 & 0.0 & 0.00 & +0.2 & - \\
\hline 3 & 282 & -1.6 & 0.28 & -1.2 & 0.21 & -0.4 & 0.08 \\
\hline 3 & 445 & -1.5 & 0.27 & -1.0 & 0.19 & -0.4 & 0.08 \\
\hline 3 & 611 & -1.8 & 0.32 & -1.3 & 0.23 & -0.5 & 0.09 \\
\hline 3 & 779 & -1.6 & 0.21 & -0.9 & 0.17 & -0.2 & 0.04 \\
\hline
\end{tabular}




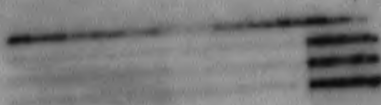

$-10-$

5.0 CORROSION DATA (COIT'D)

\section{TABUS III}

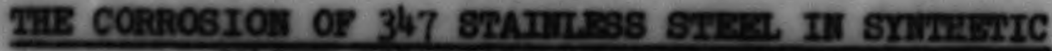

WASTE SOLWIONS AT 105-108\%C

\begin{tabular}{|c|c|c|c|c|c|c|c|}
\hline & Exposure & Total & ersion & Lesqus & -Vapor & & \\
\hline iolut1on & & nda & Ey & 래d & Epy & 垔 & Exy \\
\hline $\begin{array}{l}1 \\
1 \\
1 \\
2 \\
2 \\
1 \\
2\end{array}$ & $\begin{array}{r}21 \\
91 \\
162 \\
328 \\
494 \\
660 \\
828\end{array}$ & $\begin{array}{l}-24.0 \\
-1.9 \\
-0.9 \\
-0.3 \\
-0.3 \\
-0.4 \\
-0.3\end{array}$ & $\begin{array}{l}4.30 \\
0.30 \\
0.20 \\
0.06 \\
0.06 \\
0.07 \\
0.06\end{array}$ & $\begin{array}{l}-309.0 \\
-71.3 \\
-39.4 \\
-19.5 \\
-13.0 \\
-11.0 \\
-7.9\end{array}$ & $\begin{array}{l}55.8 \\
12.1 \\
7.1 \\
3.5 \\
2.4 \\
2.0 \\
1.4\end{array}$ & $\begin{array}{l}-11.8 \\
-3.1 \\
-0.9 \\
-0.3 \\
-0.4 \\
-0.5 \\
-0.3\end{array}$ & $\begin{array}{l}2.10 \\
0.60 \\
0.20 \\
0.05 \\
0.07 \\
0.09 \\
0.06\end{array}$ \\
\hline $\begin{array}{l}2 \\
2 \\
2 \\
2 \\
2 \\
2 \\
2 \\
2 \\
2\end{array}$ & $\begin{array}{r}21 \\
91 \\
162 \\
328 \\
494 \\
660 \\
828\end{array}$ & $\begin{array}{r}-15.3 \\
-4.1 \\
-1.2 \\
-0.7 \\
-0.8 \\
-1.0 \\
-0.7\end{array}$ & $\begin{array}{l}2.80 \\
0.74 \\
0.22 \\
0.13 \\
0.15 \\
0.18 \\
0.13\end{array}$ & $\begin{array}{l}-8.8 \\
-2.3 \\
-0.4 \\
+0.03 \\
-0.3 \\
-0.5 \\
-0.3\end{array}$ & $\begin{array}{l}2.60 \\
0.40 \\
0.07 \\
0.05 \\
0.09 \\
0.05\end{array}$ & $\begin{array}{l}-7.7 \\
-2.5 \\
-0.7 \\
-0.2 \\
-0.3 \\
-0.5 \\
-0.2\end{array}$ & $\begin{array}{l}1.40 \\
0.44 \\
0.12 \\
0.04 \\
0.05 \\
0.09 \\
0.04\end{array}$ \\
\hline $\begin{array}{l}3 \\
3 \\
3 \\
3 \\
3 \\
3 \\
3 \\
3\end{array}$ & $\begin{array}{r}21 \\
91 \\
162 \\
328 \\
494 \\
660 \\
828\end{array}$ & $\begin{array}{r}-20925.2 \\
-4828.6 \\
-2642.2 \\
-1334.6 \\
-886.6 \\
-664.0 \\
-528.9\end{array}$ & $\begin{array}{r}3779.1 \\
872.1 \\
477.2 \\
241.0 \\
160.1 \\
119.9 \\
95.5\end{array}$ & $\begin{array}{l}-6714.6 \\
-1549.8 \\
=829.7 \\
=419.7 \\
=282.7 \\
=212.3 \\
=169.3\end{array}$ & $\begin{array}{r}1212.6 \\
279.9 \\
149.8 \\
75.8 \\
51.1 \\
38.3 \\
30.6\end{array}$ & $\begin{array}{r}-17.0 \\
-4.5 \\
-1.8 \\
-0.8 \\
-0.6 \\
-0.7 \\
-0.4\end{array}$ & $\begin{array}{l}3.10 \\
0.80 \\
0.30 \\
0.14 \\
0.11 \\
0.13 \\
0.08\end{array}$ \\
\hline
\end{tabular}


6.0 DISCUSSTOH OF DATA

The Effect of Chloride Concentration. The effect of increasing the choride concentration fros $0.00 \mathrm{M}$ to $0.028 \mathrm{M}$ in the test solutions was to increase the corrosion attack on all three types of stainless steel by varying degrees of intensity. This phenomenon is clearly shown by an inspection of the data in the preceding tables. A mild. increase in the corrosion rate for 309 stainless steel was observed on the specimens exposed under conditions of total imersion, Iiquid-. vapor exposure, and vapor exposures. The most pronounced increase occurred on the total-immersed specimen with 0.026 sodium chloride concentration; the rate increased from $0.16 \mathrm{mil} /$ year to $1.4 \mathrm{mils} / \mathrm{year}$. The least effect of increased chloride concentration vas noted on the vapor-exposed specimen; here, the rate increased from 0.02 to 0.03 mil/year. Corrosion attack on the liquid-vapor specimen increased by a factor of 10 , from 0.1 to $1.0 \mathrm{mil} /$ year, as the sodium chloride vas increased fron $0.007 \mathrm{M}$ to $0.028 \mathrm{M}$. Type 316 stainless steel showed excellent resistance to the effect of increased chloride concentration. For conditions of total immersion, the rate increased from 0.2 to 0.28 $\mathrm{mil} /$ year; for conditions of liquid-vapor exposure, the rate increased from 0.15 to $0.17 \mathrm{mil}$ /year, and for conditions of vepor expsoure, corrosion decreased from 0.05 to 0.04 mil/year. By far, the most severe corrosion attack as a result of the increased chloride soncentration. occurred on the 347 stainless steel specimens. Under conditions of total inmersion, the corrosion rate increased from $0.06 \mathrm{mil} /$ year to $95.5 \mathrm{mils} /$ year as the sodium chloride concentration vas increased from $0.007 \mathrm{M}$ to $0.028 \mathrm{M}$. These rates are based on a total exposure of 828 hours. The 11quid-vapor specimens exhibited an increase from 1.4 to 30.6 mils/year under similar conditions. The specimens exposed to the vapors showed a very slight increase, 0.06 to $0.08 \mathrm{mil} / \mathrm{year}$, as the chloride increased.

These data show that corrosion attack is directly influenced by chloride concentration. The nost severe effect of increasing chloride concentration occurred under conditions of total exposure; the least severe effect occurred under conditions of exposure to the vapor phase. Type 316 stainless steel exhibited the most superior corrosion resistance to all three types of exposure; total imersion, 11quid-vapor, and vapor.

Figures 1, 2, and 3 show graphically the effect of increasing the sodium chloride concentration on the corrosion of the three stainless steels.

A question of doubt was raised as to whether or not there was any escape of the chloride ion from the test solution during its operation. Since the same solutions were used throughout the tests, the escape or chloride during the early stages of the test would lead to erroneous conclusions on the determination of corrosion resistance. It vas believed that escape of chloride could not occur under the conditions of total reflux by wich the tests vere run but an additional test was conducted to check specificaliy for this effect. Type 316 stainless steel was selected for the test since 1t had show the nost favorable corrosion resistance; Solution 3 was selected because $1 t \cdot$ contained the 
$-12$.

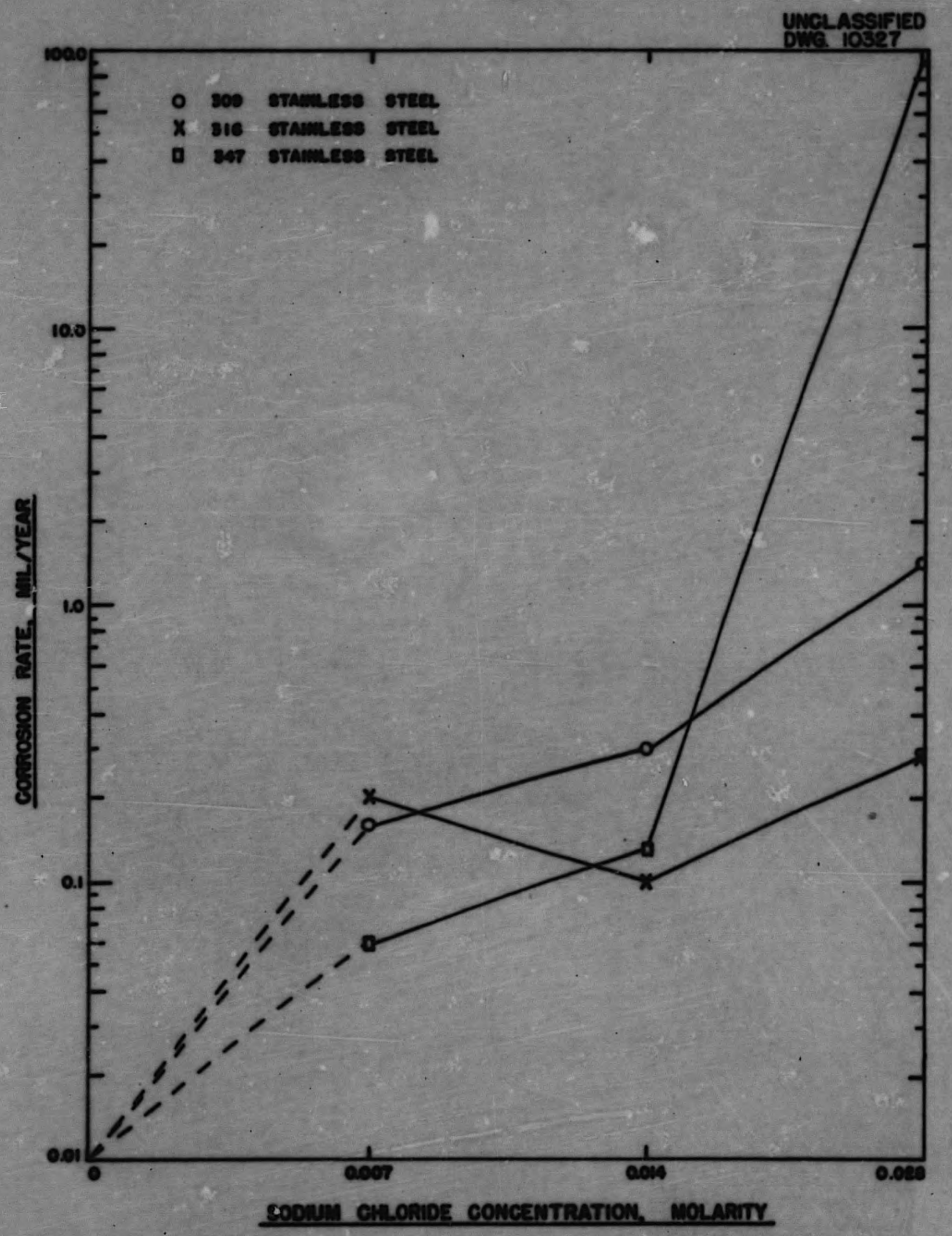

FlG.1 The EFreet of soonn culoaibe concentration on the connosion of TOTALi ImaEnsED STAMLESS STEEL SPECIMENS IN SWMTUETIC

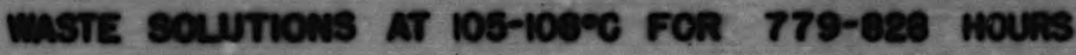


$-13-$

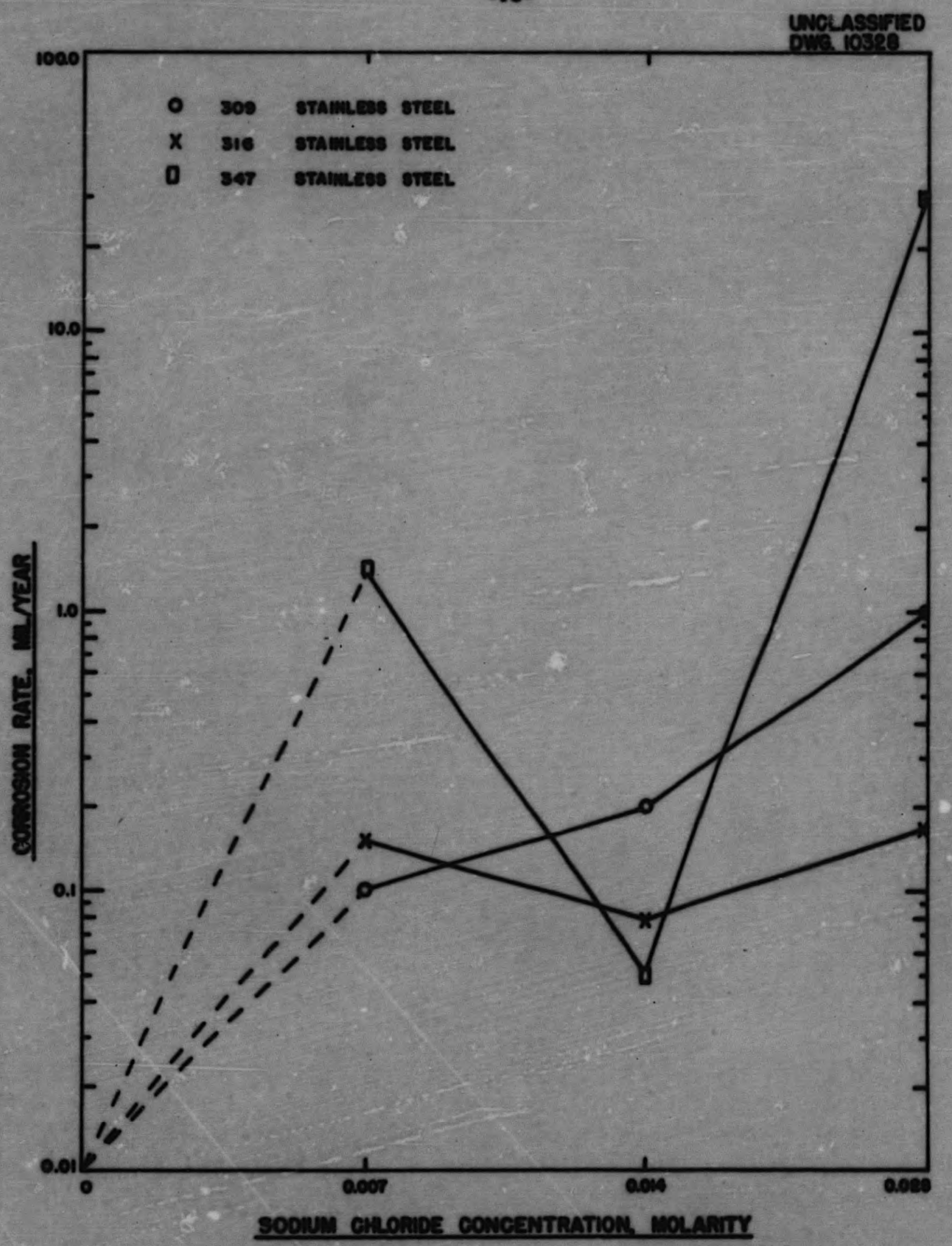

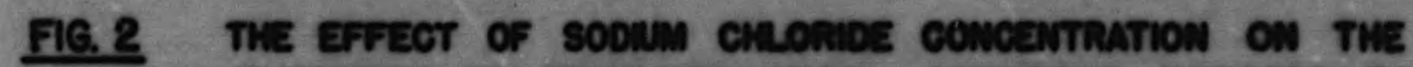
CONAOSIOU OF STAWLESS STEEL SPECNEENS EXPOSED TO LLUID-VAPON PMASE OF SVWTVETIC WASTE SOLUTIOWS AT 105-1000 FOA $779-628$ nouns 


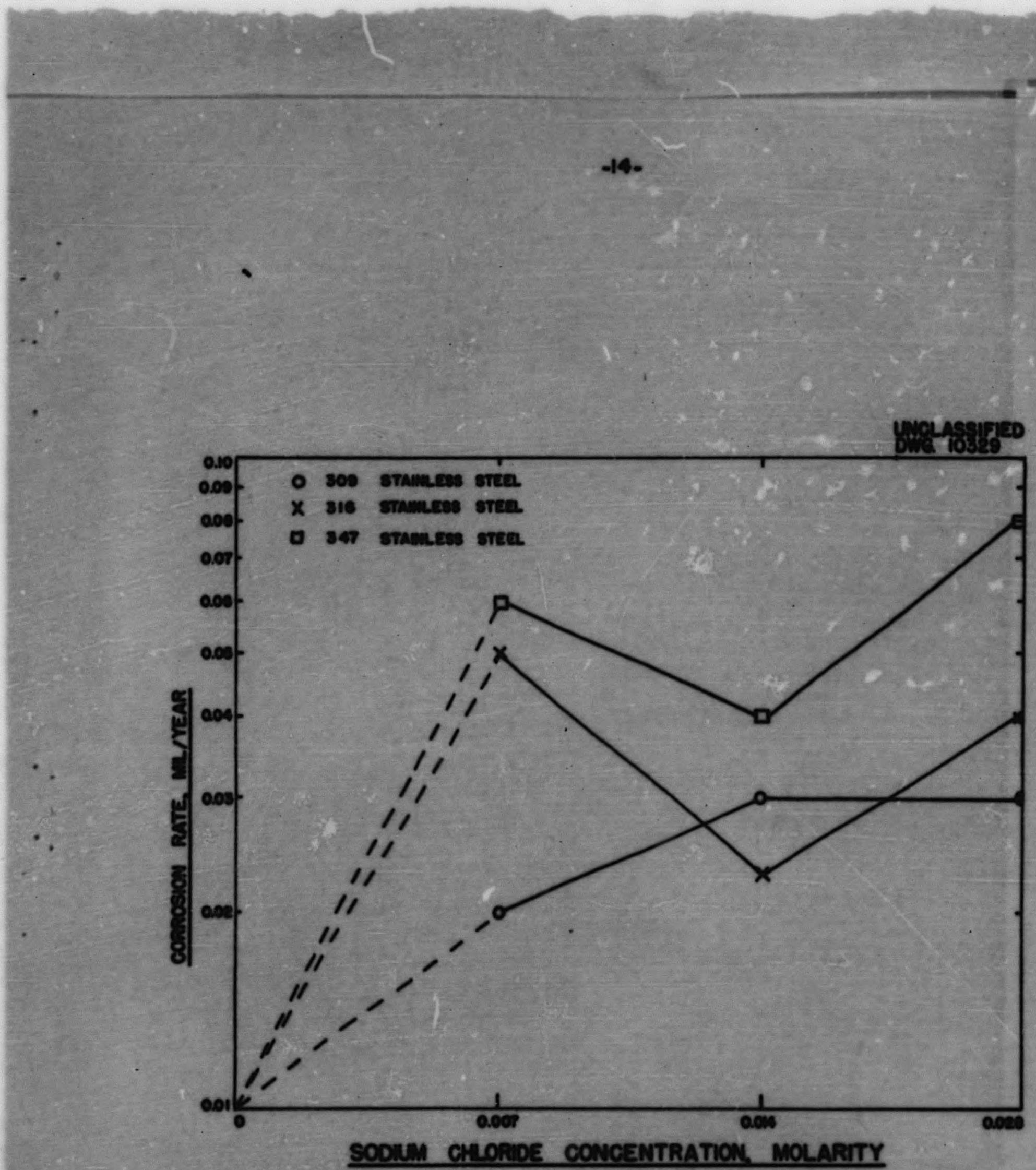

E16.3 The EFFer of soomen cmenus concentration on The connosion of stantuEsS STEEL SPECIMENS ENOSED

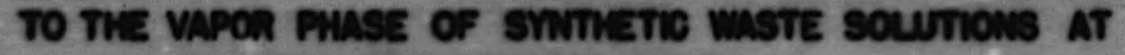
106-10006 FOR Tr9-eed nouns 
6.0 DISCUSSION OF DATA (COII'D)

highest sodium chloride concentration, $1.64 \mathrm{gm} / 11$ ter, and was the lost corroeive test solution, and condition of totel inersion vas selected because it represented the most severe corrosion exposure.

This test vas run in exactly the same manner as the tests already described except for one condition; the test solution vas removed at the end of 48 hour periods and repleced with coupletely nev colution. This procedure was repeated eight times. Sarples vere weighed at the end of each 48 hour period and sodium chloride anelyses vere made on the final test solution for each period of exposure.

Duplicate specimens of 316 stainless steel vere used and the ilgures included in the folloving table represent average values.

\begin{tabular}{|c|c|c|c|c|}
\hline Total & Sodiun $\mathrm{Ch}$ & e, es & Cunure & t. Loss \\
\hline $\mathrm{hr}$ & In1tial & Final & 로 & Edd \\
\hline & 1.64 & 1.75 & 2.9 & $7 . \frac{1}{6}$ \\
\hline & $\begin{array}{l}1.64 \\
1.64\end{array}$ & $\begin{array}{l}1.72 \\
1.72\end{array}$ & $\begin{array}{l}2.3 \\
3.7\end{array}$ & $\begin{array}{l}1.6 \\
3.0\end{array}$ \\
\hline 192 & 1.64 & 1.43 & 3.3 & 2.0 \\
\hline 240 & 1.64 & 1.72 & 2.6 & 1.3 \\
\hline & 1.64 & 1.66 & 3.1 & 1.3 \\
\hline 336 & 1.64 & 1.70 & 4.1 & 1.5 \\
\hline 400 & 1.64 & 1.72 & 5.0 & 1.5 \\
\hline
\end{tabular}

Corrosion Rate nil/vear

-Th1s is not a result of a chentcal anelysis, but represents veighed amounts of sodiun chioride which were added in the preparation of the teat solution.

These date show conclusively that the test nethod vas eatisfactory and that there vas no escepe of chloride from the systen. The slight discrepancy between Initial and finel chloride concentrations na be attributed to a combination of amell error in initiel veighing of the sodium chloride and the plus or minus varlations in the aceuracy of the analytical determinations. The iportant fact renains thet the finel sodium chloride concentrations vere sufriclently conotant to elininate any poseibility that chloride hed escuped cluring the operation of the teat.

The corrosion rate of 0.3 mil/year for the 316 stalnless steel after 400 hours is in excellent agreement with the corrosion rate of 0.27 mil/year for 445 hours as shown in Table II.

The Effect of Total I llersion. Under conditions of total Inaraion, Type 316 stainless steel exhibited the best all-around corrosion re. sistance to the three test solutions. Based on individual solutions, the following table presents a listing of the stainless steels in order of their pseferred selection in the three test solutions: 


\section{$\exists=$

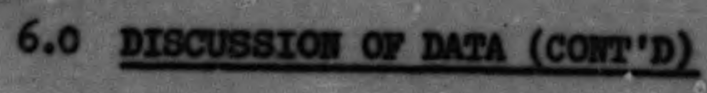 \\ $-16$.

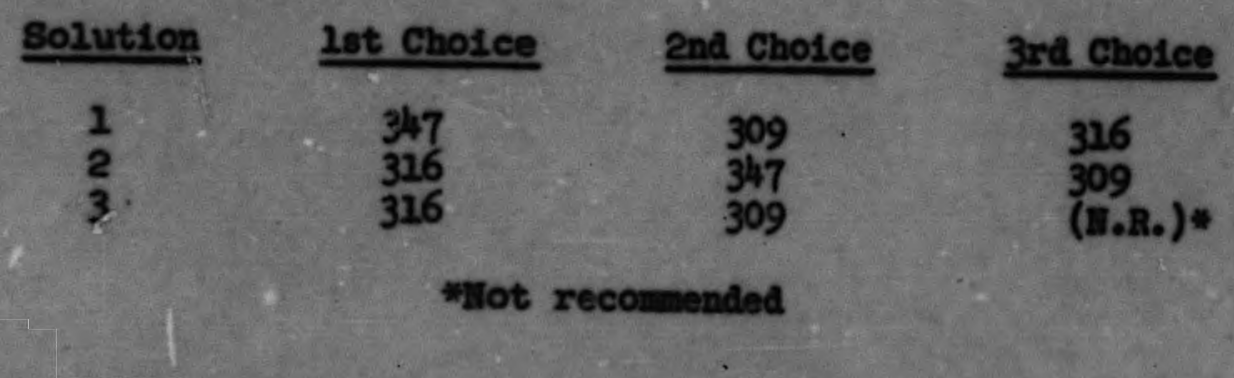

The corrosion rates for 309 and 316 stainless steels in solution 1 vexe nearly 1dentical, thus making the use of elther meterial satisfactory

Figure 4, 5, and 6 are graphic presentations which show comparatively the corrosion attack on the three stainless oteels exposed to conditione of total inersion in the three test solutions.

The Befect of Liquid-Vepor Frosure. In general, corrosion attack on specinens wich were exposed to the 11quid-vapor interface was not as pronounced as for conditions of total exposure. In the former tests, Epecimens were located in the teat flaske so that epproximately 50\% of the surface area was in the solution and the other $50 \%$ vas exposed to the vapor. The most severe corrosion was exhibited by 317 otainless steel in Solution 3. Here, the corrosion rate was $30.6 \mathrm{milo} / \mathrm{year}$ after 828 hours of test. A table showing the selection preference of the stainless steels in the three test solutions for liquid-vapor exposure
is listed as follows:

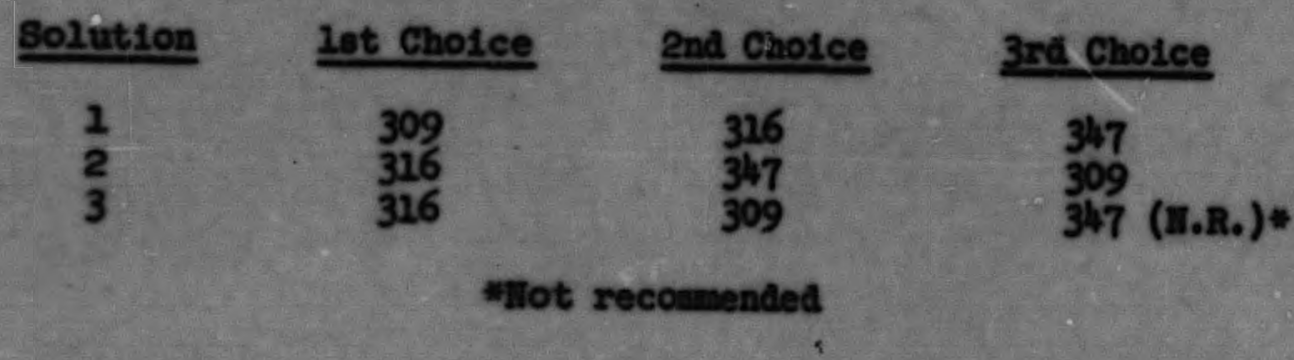

Figures 7, 8, and 9 present a eraphile colparison of the corrosion rein the three syntbetic vaste solutions. 


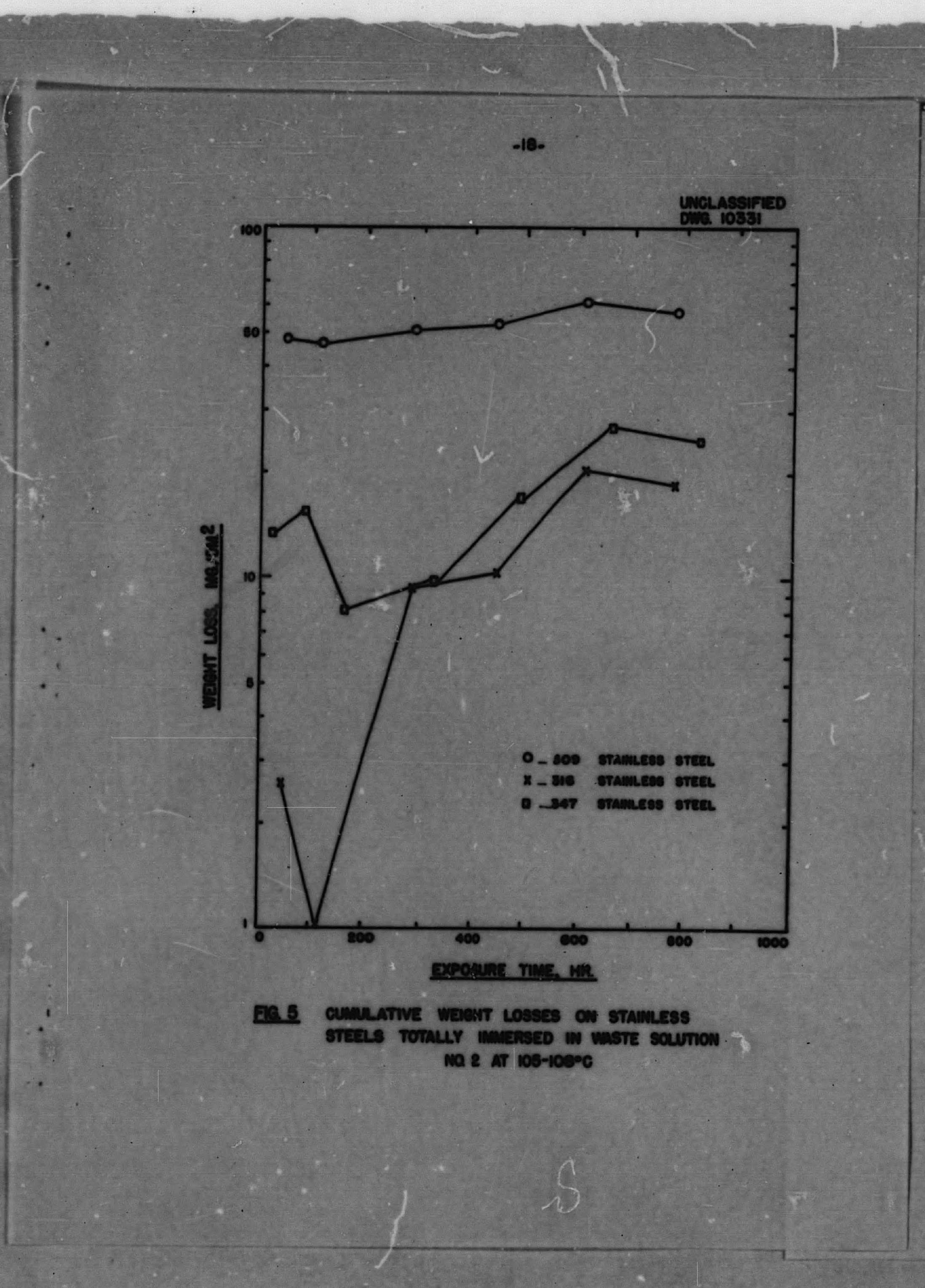


$-20$

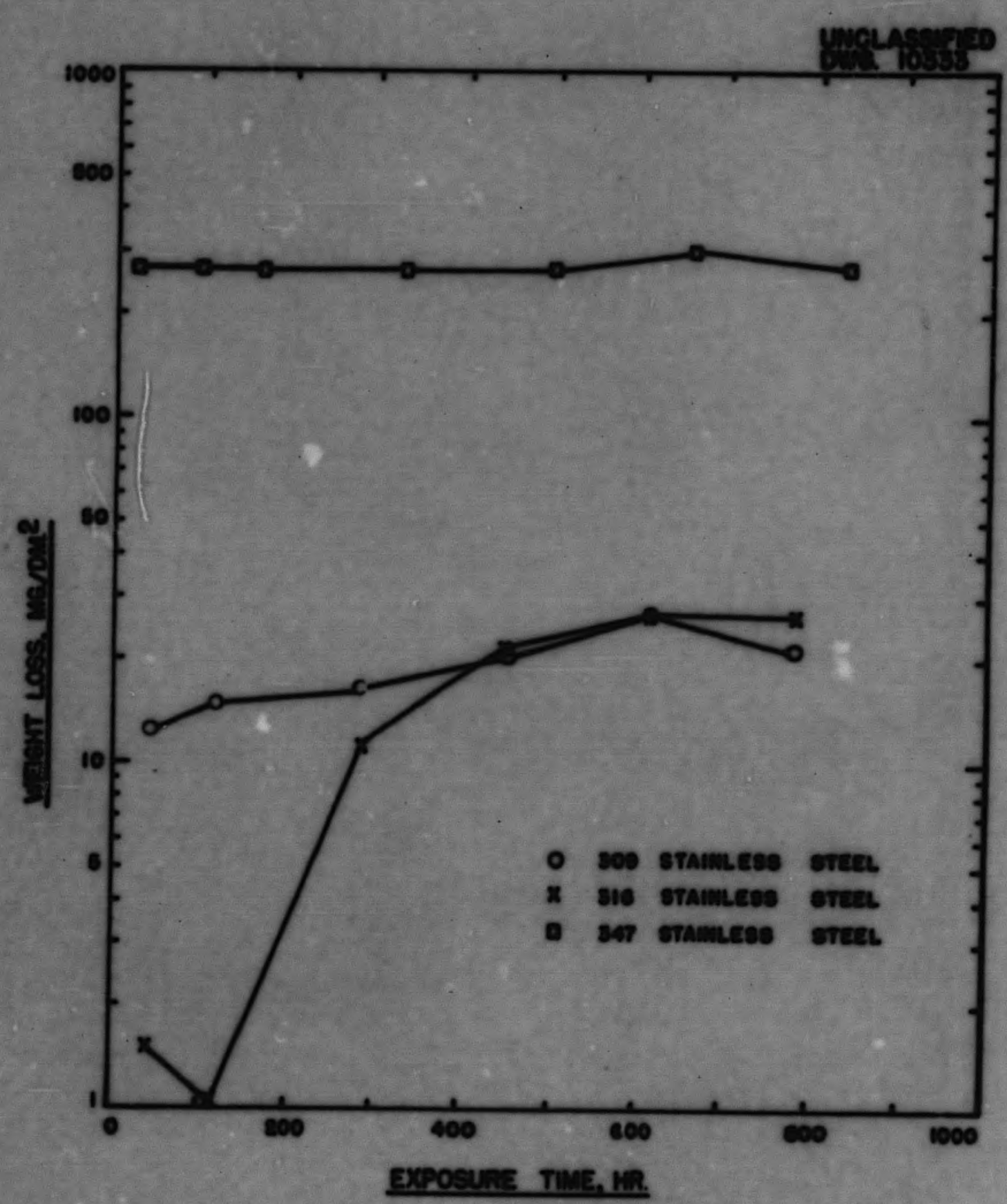

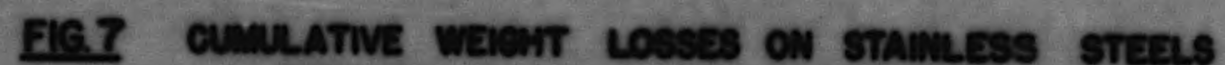
Exosev to The Leuld-vapon Pusse w unste soumon wa. AT 105-100\% 
-21.

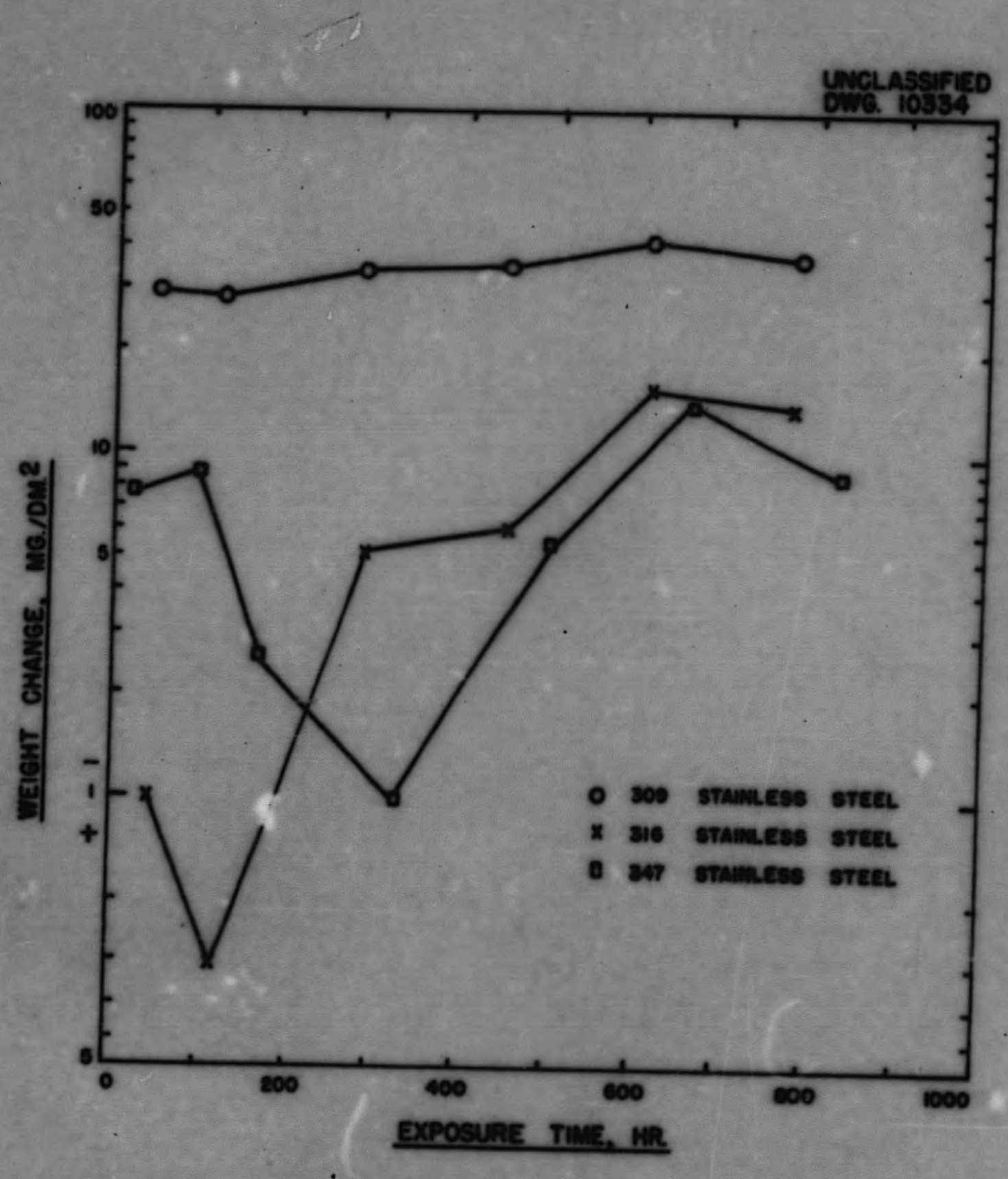

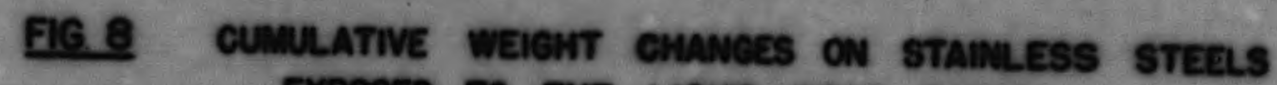
EXPOSED TO THE LIOUDD-VMPOR PMASE

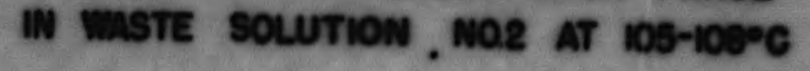


$-22$.

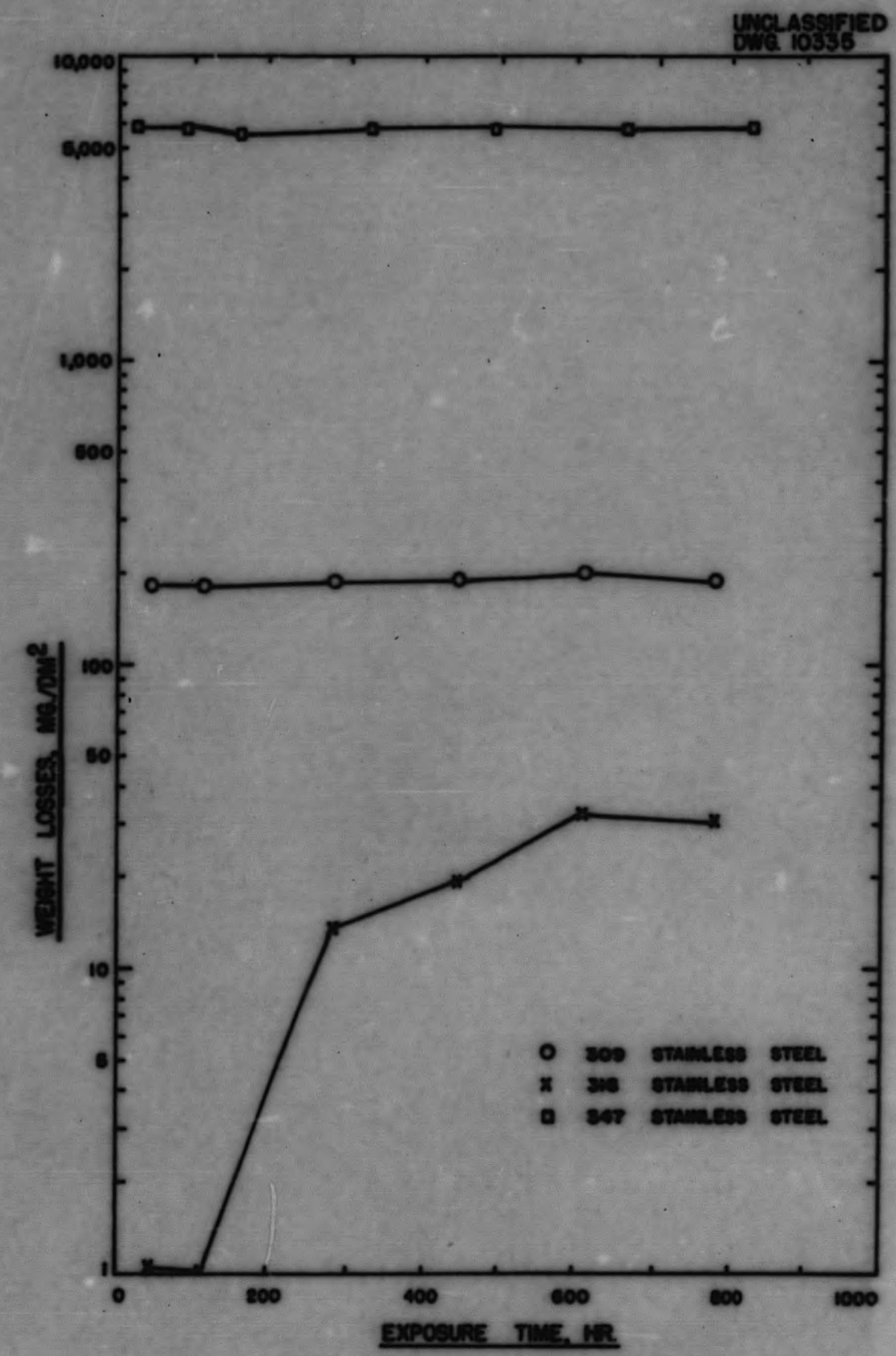

Fig.9 CUMLATIVE wEIGNT LOSSES ON STAMLESS STEELS EXPOSED TO TVE LIOUD-VAPON PMASE w waste soLUTION No.3 AT $105-100^{\circ} \mathrm{C}$ 


\section{$\equiv$}

$-24-$

7.0 conchusions

The use of 316 stainless steel for the construction of distillation and evaporation equivent showld be made with certain considerations, expecially where velaing operations are involved. The aaterial can be welded without difficulty, but is somenhat susceptible to carbide precipitation. The maximum carbon content or 0.10 percent tends to minimize the extent of this carbide precipitation. In cases where the corrosivenest of the solution being used is not tog severe and where service tenperatures do not fall in the range of $900-1600^{\circ} \mathrm{Y}$, the steel may be used satisfactor $11 \mathrm{y}$ in the as-weided condition. On the other hand, when the solution is coror Solution 3 in this investigation, it is reconnended that an anneailns process follow the velding operation in order to oblain maximum corrosion resistance. The annealing operation consists of heating the fabricated parts to $1950-2000 \%$ for an established time and then cooling quickly through the range of $900-1600 \%$. This process reaissoives any attack under severe operating conditions.

8.0 ACKROWL BDGEOGINS

The writer wishes to express his appreciation to L. L. Toirchile and J. W. Brown for their assistance in the preparation of test specimens, test solutions, and formal preparation of graphs. 